\title{
How ready is China for a China-style world order? China's state media discourse under construction
}

\begin{abstract}
What is exactly a China-style world order that Chinese officials and intellectual elites have been recently talking about, and how ready is China for it? An examination of the discourses by major state media for the promotion of China's voice and image abroad, contextualized and enhanced by extensive in-depth interviews, confirms that although China has shifted from the low-profile approach to a more assertive one wanting to change the global order, its verbal challenge and sometimes harsh criticism of the US-led international system is accompanied by an obvious absence of a clear vision of what the new world order should be like. This lack of a clear vision, this paper argues, is due to the fact that the Chinese discourse on world order is still work-inprogress, constrained by internal practices, and Africa is its testing ground for the construction of a discourse that China hopes to be an alternative.
\end{abstract}

\section{Keywords}

International community, new world order, Sino-African relations, soft power, state media discourse, testing ground 


\section{Introduction}

An examination from March to April 2011 of the English websites of China Daily and Xinhuanet for the presentation and representation of China-Africa relations is conducted in the context of China's endeavour to build up and enhance its ability to influence other nations. The examination of the two major official outlets for the promotion of China's voice and image abroad reveals emerging discourses from China calling on developing nations for a new global order. It shows that Chinese official media not only aim to guide global views of contemporary Sino-Africa relations, but also attempt to create a discourse on international affairs as an alternative to what is perceived by the Chinese as a 'Western discourse'.

As expected, both China and African countries receive overwhelmingly positive coverage, and negative issues tend to be reported positively. The relationship between China and Africa was portrayed as a mutually beneficial one and based on principles of equal partnership rather than a neo-colonialist attitude. Within expectations as well, they tend to be reports only, with no in-depth analysis. This, according to one interviewee in Beijing, is in line with China's general principle of non-interference in dealing with other countries. Another noticeable feature shared by both websites is that media in some African countries is often cited to combat or counteract concerns over Chinese intentions and strategic aims in Africa (e.g., 'China is welcomed by Africans'; 'China does not bring harm to Africa'), rather than simply rejecting them.

But most importantly, the examination reveals emerging discourses which call on Africa to change the existing world order. They highlight consensus, common stand and prosperity between the nations, who are urged to move beyond economy to work together on restructuring the world order, including a comprehensive reform of the UN with its Security Council, monetary, diplomatic relations and global politics.

The discourses confirm that China's bilateral relations with countries in Africa indicate a newer, emerging rhetoric of global partnership based on equality. It also means that China continues to identify itself as a developing country. But this time it aligns with them to challenge the West-dominated global order. In so doing, China has 
shifted away from the low profile approach introduced by Deng Xiaoping in the early reform period to focus national energies on economic growth and domestic stability. Observers of China may question if China by 2008 really performed the way as Wen described it in his 'Report on the Work of the Government for 2008', it nevertheless confirms the shift in China's foreign policy from the low profile approach to actively participating in international affairs during Hu-Wen 's first term between 2003 to 2008 Wen 2008):

We appropriately responded to new challenges in the international arena, actively and responsibly participated in efforts to resolve global issues, and played an important and constructive role in the resolution of issues concerning international and regional hotspots.

With more openness to the world China is no longer content with 'playing the game created and defined by the world's advanced industrial economies, most notably the United States,' (Steinfeld 2010) or to continue to work largely 'within the existing international order and conciliated the big powers,' (Yan and Sautman 2012) but is keen to have a say in international affairs. To do that, China greatly increased its investment in the state media to air its views, break the Anglo-American monopoly and enhance China's international influence. Organizations such as China Central Television (CCTV), Xinhua News Agency and People's Daily could reportedly receive up to RMB 15 billion (U.S. \$2.19 billion) respectively for ambitious schemes geared toward enhancing China's international influence (Lam 2009). For instance, the national flagship media CCTV's efforts to compete with CNN or BBC is obvious in its constant change of names -- within a few years, it has changed its name from CCTV-9 to CCTV International, and finally to CCTV News.

Many scholars and observers of China alike have argued that China is becoming more assertive as its interests and capabilities grow (e.g., Callahan 2012: 22; Zhang 2008). With an increased sense of confidence, pride and ambition derived from its growing economic and military power, discussions for a Chinese-style world order emerge. Many Chinese public intellectuals have been publishing books and articles describing 
China's future as the world's future. For instance, In 2030 China Hu Angang concludes that China will create a Sino-centric world order to establish the World of Great Harmony, which is not only 'China's dream,' but is also the 'world's dream' (Hu et al 2012).

China's political leaders have also been presenting Chinese visions of future world order. In September 2005, Hu Jintao introduced 'harmonious world' as a new way of thinking about global politics at the podium of the UN General Assembly. This harmonious world, Hu explained, would allow the coexistence of different civilizations. It is different from the west-dominated world order, and to challenge the existing world order, China needed not only to increase its level of 'dealing with the international situation and international affairs,' but also 'to have more influential power in politics' (Wang 2012). This is an indication of the start of a further shift:

Low profile $\longrightarrow$ Active participation $\longrightarrow$ Challenge

$\mathrm{Hu}$ Jintao's speech on world order at the opening ceremony of the Fifth Ministerial Conference FOCAC in 2012 shows that China has definitely gone beyond active engagement with the existing order to achieve a higher power ranking, to actively calling for changing the existing international architecture in the second term of $\mathrm{Hu}-\mathrm{Wen}$ :

In so doing, we have upheld the common interests of developing countries, promoted democracy in international relations, and we are working to make the international order more just and equitable.

Peace, development and cooperation remain the trend of our times. ... . The unjust and inequitable international political and economic order still affects and hinders world peace and development.

Two things are certain: first, there is recognition and consensus in China that it should move from a low profile to a more confident and assertive approach. Secondly, harmony is the core value in China's vision of the world. The questions to ask then are, although 'the new leadership is well prepared to deal with the international system and its institutions,' (Shen 2012) what does harmony exactly mean in this Chinese-style world 
order? In other words, what alternative norms and policies is China promoting for the reshape of the international system?

To answer the questions, the author conducts an examination and analysis of Africa Live produced by CCTV Africa in Nairobi, CCTV's first overseas news center. The programs examined are broadcast on the global English CCTV News and span from 11 January when it was launched to the end of April 2012, when the investigation started. There are two reasons for choosing Africa Live: first, the shift in China's approach to foreign policies is reflected in its shift from wanting its voice to be heard ('right to speak') to the 'power of discourse,' (Zhao 2011) a discourse that should not only be different from the West but can also conquer the global discussion of norms and values. An official in Beijing said during an interview on the power of discourse in 2011, 'Human right is a concept from the West. We will not win if we try to highlight this concept.' At the Symposium on 'Trend in African Development and Prospect of Sino-Africa Relationship' held in April 2011, Qu Xing, president of China International Affairs Research Institute, called on Chinese academia to construct a non-West discourse. The examination will thus reveal what discourse or new concept of the world order China's major state media wants to project.

Secondly, language and images projected by state media are important tools in creating and maintaining particular points of views among politicians, policy makers and the public. State media play an important role in communicating a country's effort to bring about understanding for its nation's ideas, culture, national goals and current policies. In the case of state media in China, they play an even more important role in conveying the messages from the State as the whole apparatus is under the Propaganda Department of the CCP. Although the domestic media environment is increasingly diverse and far from being monolithic, the discussions on the state media for overseas audiences suggest at least some level of leadership support.

This paper identifies and analyses the main themes of the discussions on Africa Live targeting at an international media public, with a view of revealing how China is intending to reshape the contours of the world system. The analysis is supported by extensive in-depth interviews with officials, media professionals and academics in 
Beijing in 2011 and 2012, and with local and Chinese employees for CCTV Africa in Nairobi in 2012. Reviews of literature on the subject both in English and Chinese ensure the analysis of the discourses is tied to larger historical and political frameworks to achieve greater interpretive coherence. It is also important to make clear at the start that this paper does not focus on the validity of what is reported in the CCTV coverage. Important as it is, the paper examines the state media discourse for values and norms it is trying to project.

\section{Why Africa? Why CCTV Africa?}

Over the past decade, China's presence in Africa has become more visible than any other countries. In fact it is one of the regions where China is more active than ever: today, China is Africa's largest trading partner, and the bilateral trade volume surges from $\$ 10$ billion in 2000 to more than $\$ 160$ billion in 2011, according to the website of the Chinese Communist Party (CPC), Africa is also an important part of $\mathrm{Hu}$ 's harmonious world; in fact, he first mentioned the concept at the Asian-African summit meeting in Jakarta in April 2005.

The scale and visibility of China's intervention in Africa have attracted much media and scholarly attention. The special issue on Sino-African relations by the China Quarterly in 2009 (Strauss and Saavedra) greatly deepens our understanding of the emerging relationship between China and Africa. Much academic research has concentrated upon aspects of Chinese foreign trade and aid policy, the role and impact of Chinese economic operations in Africa, China's influence in Africa and its implications for the West. Many analysts have also shed light on what China's real economic intentions in Africa are and how they differ from those of the West. While some have shown appreciation of China's effectiveness in delivering aid and improving infrastructure, the distinctive Chinese approach to large parts of the African continent has come under intense scrutiny. Critics have also begun to examine China's use of soft power, offering insight into the way in which soft power is playing an increasingly important role in China's relations with the world in general and with Africa in particular. A small but growing number of scholars are also starting to explain how media are caught up in China's insertion into Africa and the implications for the global 
media scape. The conferences organised by Oxford University China Africa Network, the most recent one in November 2012, have brought academic experts and practitioners together to examine and discuss the issue.

Despite the widespread attention, however, there is an under-acknowledged yet highly important point, and that is, while reversing established global perceptions of China is a priority, the state media is also using Africa as a testing ground for its construction of a discourse alternative to the West. That discourse is not only to showcase its soft power, but also to challenge the existing world power order. This understanding is not only grounded in the context of the pragmatic nature of China's foreign policy and its learning by doing approach to development at home and abroad, but also inspired by those who convincingly argued that China takes Africa as a stepping stone for global expansion: The Economist considers that China views Africa, where 'they can learn the ropes in a region where competition is weak' as a stepping stone to a greater global commercial presence (The Economist 2011). The well- known Chinese scholar, He Wenping, said that Africa is perhaps the most important testing ground for the promotion of Chinese soft power (2007), although she did not tell the reason.

Interviews with officials and media professionals also show that Africa is an important frontier where China will test and cultivate its new identity as a rising power along with its newly-found soft power by constructing a discourse on the developing world with great political-economic diversity. Some media professionals are more confident in promoting a positive image and in succeeding in spreading its influence in Africa because 'the level of the expertise and technique are lower there', while 'in the West it is harder for China to compete'. They believe what they need is a platform to practice and build up the power of discourse before they move onto some more challenging territories.

\section{CCTV Africa}

The US Secretary of State Hillary Clinton, recognising that the new battlefront is the progressively 'crowded field of state-financed satellite television news', told the Senate Foreign Relations Committee in March 2012, citing the emergence of international broadcasters Al Jazeera, Russia Today and China Central Television's CCTV News, that 
the United States is 'engaged in an information war.' And, she said, 'We are losing that w ar' (Massey).

Whether Hilary Clinton is right or exaggerating the picture, the launch of CCTV Africa, CCTV's first overseas news production centre in Nairobi in January 2012, is part of China's outreach campaign designed to cultivate the attraction of its language, culture, values and diplomacy around the world, which makes some observers believe that China has already displaced European, American and Japanese diplomatic and capitalistic soft power in many sub-Saharan African countries, 'winning influence in countries where western governments were conspicuous by their absence' (Rotberg 2008). In addition to the setting up of 29 Confucius Institutes and Classrooms in 22 African countries (Hu 2012), China's initiatives in Africa also include infrastructural and technical support to the media sector, and the greatly increased media presence, as 'China recognised the international media as an important outlet for managing and communicating a non-threatening, responsible and peaceful image' (Sheng 2008).

The engagement of the Chinese media with Africa greatly increased from 2000, when it started to work under the Forum on China-Africa Cooperation (FOCAC). The major changes came in 2006 though, when Xinhua strategically moved its Regional Editorial Office from Paris to Nairobi, a central hub in Africa for China's 'going abroad' media project. The launch of the state-run China Radio International (CRI) in Kenya in the same year can also be seen in this light. In 2008 Xinhua launched its China African News Service. With over 20 bureaus in Africa, the Chinese state news agency has become a primary source of information. Its newly developed English-language TV channel CNC World reached cable television audiences in Africa from January 1, 2011, following an agreement between CNC and South Africa-based MIH Group. Xinhua's launch of mobile news in sub-Saharan Africa in April, 2011 also enables about 17 million Kenyan mobile subscribers to receive Xinhua's latest news. The speed and scale of the expansion of the Chinese media is especially noticeable at a time when many Western media houses are cutting back on their overseas operation budget.

The launch of CCTV Africa is thus considered a vital step in challenging the longstanding Western monopoly by creating its own news providers to tell the China story on global affairs, especially African, and to win over the hearts and minds of everyday people who have traditionally learned about the country through global 
political news circles. It offers insightful information thanks to its close relations with African political elites. For the same reason, the one hour program Africa Live is broadcast right after the local news program and weather forecast from 8:00 - 9:00pm local time to ensure a decent reception rate. It is also regarded as a crucial measure toward the completion of CCTV's global news gathering network to enhance its competitiveness. Shortly after CCTV Africa was launched, CCTV America followed suit: in February 2012 CCTV News launched CCTV America, which offers a daily program schedule from new studios and a production center in Washington D.C.

\section{Findings and analysis}

CCTV Africa provides an-hour long program Africa Live for the global CCTV News in English every day. It consists of African News with the weekly series of 30-minute documentary program, Faces of Africa, on Monday, and half an hour on Talk Africa, featuring interviews on current affairs in Africa. An examination of the programs reveals some significant reoccurring themes.

\section{Africa News}

Data is collected every fifth day from the first program on 24.01.2012 to 30.04.2012, so that the data from 21 days altogether covers three Mondays, Tuesdays, Wednesdays, Thursdays, Fridays, Saturdays, and Sundays respectively.

Five highly noticeable features are found from the programme: first, as the figure show s below, contradictory to the findings from China Daily and Xinhuanet, there is not a clear tendency tow ards positive news on Africa. In fact as the figure below shows, on many days negative reporting outweighs positive reporting on Africa.

\section{Figure 1}




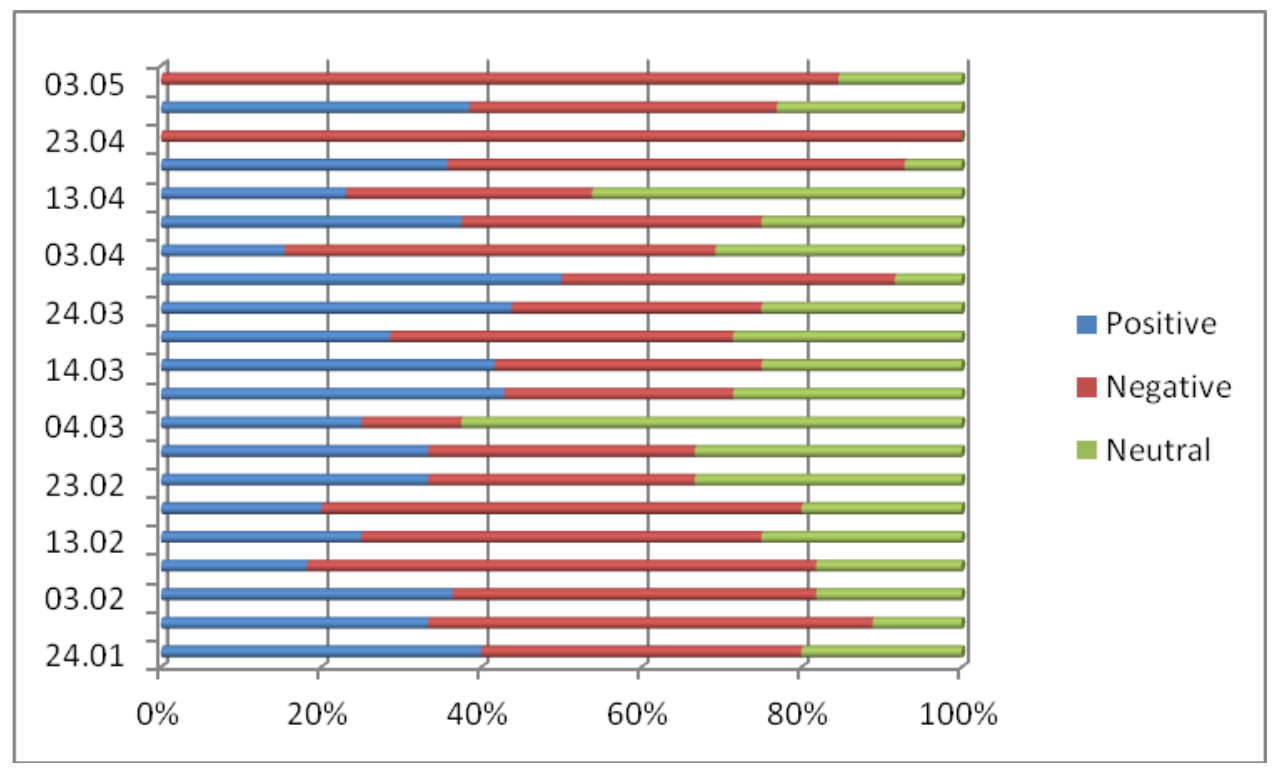

Secondly, of the 21 days' programs China appears 10 times, with the majority on China coming to provide aid to different African countries including medical help, investment, or cultural exchanges. Three of the China-related items are non-Africa related but all give positive images of China.

In contrast however, quite a few of the items are negative reports on the USA. For instance, there is one non-Africa related item on American airliners losing jobs, one critical of the USA's sanctions which forced an Angolan State oil company to pull out of a $\$ 7.5$ billion natural gas project in Iran. There is also one on the conflict between Egypt and the USA over a travel ban on foreign NGO employees in Egypt, two on US soldiers killing Afghan citizens, with one relating it to Obama's visit.

The fourth obvious theme running through the news items is China's critical view on EU and some established international practices: four items on EU's high carbon tax, two challenging the World Bank for automatically giving the Presidency to an American, thus raising a question mark on the merit and transparency of the selection process. One negative report is on European unemployment which has risen to the highest level in 14 years, while one piece of sports news is critical of the divide between east Africa and Europe.

Finally, throughout the program, solidarity and camaraderie is demonstrated by item s on collaboration with Africa on the international stage, such as the one on the Indian Airlines, the Chinese, and African Aviation Authorities opposing the carbon scheme 
together, and the one on Russia and China blocking a UN move to force President Assad in Syria to step down. This is obviously a footnote to Hu' Jintao's remarks in his Report to the $18^{\text {th }}$ Party Congress: 'China opposes any foreign attempt to subvert the legitimate government of any other countries.'

\section{Talk Africa}

This 30-minute Sunday current affairs program 'discusses the pertinent issues affecting the African continent.' High level officials including Kenya's Vice President, Malawi's President, Ethiopia Prime Minister, as well as scholars from both within and without Africa have been guests on the show. In fact the first invited to the program was Kenya's Vice President who showed his support at the launch of CCTV Africa.

Table 1

\begin{tabular}{|l|l|}
\hline Dates & Titles \\
\hline 15.01 .2012 & How Africa can reposition herself in int'l affairs \\
\hline 22.01 .2012 & Egypt in tran sition \\
\hline 29.01 .2012 & The changing face of Africa \\
\hline 05.02 .2012 & Africa's food security \\
\hline 12.02 .2012 & AU elections charter \\
\hline 19.02 .2012 & Libya in reconstruction \\
\hline 20.02 .2012 & New hope for Somalia \\
\hline 04.03 .2012 & Senegal's election \\
\hline 11.032012 & Rwand a's phenomenal Rise from the ashes \\
\hline 18.03 .2012 & Lord's Resistance Army \\
\hline 25.03 .2012 & New Milestone in Sudan talks \\
\hline 01.04 .2012 & Charting a new economic path \\
\hline 08.04 .2012 & Africa's oil wealth \\
\hline 15.04 .2012 & Somalia post TFG \\
\hline 22.04 .2012 & Mali in transition \\
\hline 29.04 .2012 & The Taylor verdict: what it means for Africa \\
\hline
\end{tabular}


Six recurring themes are found from the programs. Some of them re-enforce China's stand demonstrated in the news program Africa News:

1. Condemnation of Western intervention in African affairs

2. Democracy, revolution, election s, crisis and stability

3. Reforming international systems

4. Chinese support without conditions and China's role in Africa

5. China's construction of the African image

6. Questioning USA's behavior in Africa

In addition to the above outstanding themes, there is one noticeable feature, and that is the challenge for the presenter of the program, who frequently encounters liberalminded discussants.

\section{Condemnation of Western interventions in African Affairs}

In contrast to the Western 'political conditionalities' and calls for 'good governance', China has stood by the principle of non-interference and non-intervention in its foreign and Africa policies, and remained highly critical of foreign interventions in African affairs (although see e.g., Large 2008). It strongly supports the African Union (AU) in exercising its power over African affairs. In the following program, for instance, NATO Allies was challenged for ignoring the stand of the AU for dialogue over what happened in Libya (How Africa can reposition herself in int'l affairs):

Presenter (P): When we look back at what happened in Libya the AU had a stand for dialogue. NATO Allies had a different stand. In the end it was foreign intervention. So what is Africa's position in an issue like the DRC and where does that leave Africa's voice when it comes to dealing with one of its own?

Solidarity between China and Africa (Kenya) is demonstrated when Kenya's vice president Kalonzo Musyoka (KM) shows agreement: 'let us lay hold of our own destiny as a continent'. The same is true of the following:

P: You talk about a system in place, is that a domestic system, an African-led system, an African Union system? 
KM: Well they actually, basically we must build capacity for African countries them selves.

The presenter shows her suspicions of international efforts, as is demonstrated in Lord's Resistance Army, by challenging the Invisible Children for raising the awareness at the wrong time of the Lord Resistance Army and the use of child ren for fighting. At the same time, the presenter calls on African countries and individuals to play a more important role instead of getting foreign support, hence foreign interference, in this matter. As the discussants do not really answer the questions as to what African countries and individuals should do about African affairs, the presenter pushes them again for an answer.

The presenter raises similar questions about the role of AU on African Affairs and highlights the failure of foreign intervention in other programs (e.g., New Milestone in

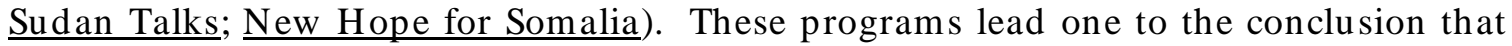
China is not only promoting non-interventionism and encouraging Africans to have control of their own affairs rather than having the West to meddle in their business, it is also 'educational', for instance by pointing out to Africans what the USA is after by sending soldiers to Uganda when there is speculation of oil in that area, as some discussants repeatedly fail to see the point.

\section{Democracy, revolution, elections, crisis and stability}

As frequent as the theme above are discussions on democracy, revolution and elections, which are taboo topics in domestic media. In fact the topic of democracy came up in the first program (How Africa can reposition herself in int'l affairs). This is different from Lee's observation that 'the Chinese elite and authorities have been for the most part interested only in economic globalization: cultivating foreign capital, markets, and technology. They are determined to keep such 'bourgeois thought' as democracy and human rights out of China's media' (Lee 2010). So the question is why there is so much discussion on these taboo topics in CCTV Africa? A close examination reveals that the presenter actively brings up the topic for the following reasons:

1. Africa should have its own style of democracy rather than copying a Western political system.

2. A close link between elections, revolution and instability. 
3. Related to the second point: stability is important for investment and economic development.

4. When it comes to reforming the international system, 'democracy' means the rules of the game created and defined by the world's advanced industrial economies, most notably the United States, should be changed and all nations should have a say.

In his report at the $18^{\text {th }}$ National Party Congress in 2012, Hu Jintao made it clear that China 'should place high importance on systemic building, give full play to the strength of the socialist political system and draw on the political achievements of other societies. However, we will never copy a Western political system.' China also supports other developing countries to develop the political system that suits the local conditions. In this sense CCTV's Talk Africa provides a platform for the deputy president of Kenya, the first invited interviewee, who is keen on a 'democracy' that differentiates itself from the 'Western democracy:'

$\underline{\text { How Africa can reposition herself in int'l affairs }}$

KM: Africans have to make democracy responsive to Africa.

So is Bingu wa Mutharika (BGWM) the former controversial president of Malawi, who believed that 'African democracy' is much more superior to western democracy' (Africa's food security).

Starting from the first program, 'political stability' is highlighted as being crucial to economic development and investment. The presenter frequently makes links between election and instability, implying that existing regimes (democratic or not) cannot be changed by opposition/dissident forces rising up against existing governments. For example:

\section{The AU Elections Charter:}

P: Isn't there the thought though that when there is an election in Africa, there is hardly ever any good news. Africa as an investment location during election years, is that still a crisis? 
While the program insists on the link between elections and stability, economic development and investment, by providing a platform to voices from Africa, CCTV is also showing that there are other countries that are also keen to have a sense of ownership of the international system. However, when it comes to reform the international system, the western concept of 'democracy' is taken up by China in arguing for an equal say for both China and Africa. As is shown in the program Charting a New Economic Path, the interview with the South African High Commissioner Ndumiso Ntsinga (NN) shows South Africa has the same desire as China to 'democratize' the West-led world order, where developing nations do not believe they have a voice:

P: $\quad$ Your Excellency, ... why is South Africa in BRICS?

NN: We've always strongly believed in solidarity amongst the countries of the south, in democratizing the international system.

NN: ... there's something wrong with the system. That the system has not been democratized, that we need to democratize the system so that we also feel a sense of belonging and feel that it is our system, it does not belong to somebody else. You look at the continental issues, for instance the issue of Libya, and the AU was almost ignored.

P: $\quad$ Do you feel that Africa still does not have a voice on the global scene?

NN: Well, I would argue that all of these are indicators of where we are, of how undemocratic the global system is.

One can draw the conclusion from the analysis that China has different attitudes towards 'democracy': when it is applied at the domestic level, then China as well as African countries should think about the local conditions and develop something that is 'superior' to Western democracy. When it comes to reforming the international system, then the western concept of 'democracy' is used to further the developing world's including China's interests.

\section{Calling for the Reform of International Systems}


An examination of the programs show that for the presenters as well as interviewees and discussants on the program, 'the international community' is almost synonymous with 'the West' (the US and Europe), and by extension 'international systems' refer to the ones set up by the West. China is now a member of the United Nations, World Trade Organization, the World Bank, International Monetary Fund, and the World Health Organization. All of them have rules and norms on global engagement that China as a member is expected to abide by. However, China does not feel that these rules were made with its participation, even if China was a founding member of the UNO and most of the IOs.

The programs, with much discussion on the need to reform global governance, reveal that China is changing its image of low-profile to one of a more confident, assertive, anti-status quo power that is pushing back against the West, and generally seeking to challenge the US-led global system. It wants to push for its own alternative and for that it need s other countries (starting with those in Africa) to feel they share the experience of being victimized by 'the West'. In this sense, it is pushing a particular diplomatic/ international agenda. In the program 'The Taylor verdict: what it means for Africa', the International Criminal Justice is repeatedly accused of targeting Africa and has a biased approach towards Africa. A similar case is made about ICT transferring one of its cases to Rwanda (Rwanda's phenomenal Rise from the ashes:

P: $\quad$ The ICT has recently transferred one of its cases to Rwanda. How significant is that for Rwanda's justice system?

P: $\quad$ Do you think it is selective ju stice?

\section{Chinese support without conditions and China's role in Africa}

China's support for Africa is noted for its 'no strings attached' approach. In the programs, in addition to framing and legitimizing its involvement with Africa, the topic of China as Africa's biggest trade partner and supporting African countries with no conditions comes up frequently. The presenter also pushes discussants for their views on China's unique no-strings attached approach. For instance:

P: One of China's top political advisors addressed the AU Summit and he talked about any assistance coming from China to Africa without any strings attached. How are African countries reading this? 
BWM: ...it's a new thing that we very much welcome... They are true friends of Africa.

In 'Libya in reconstruction', Africans are reminded of the differences between aid providers:

P: $\quad$... The cash to resuscitate the fledgling economy will not be hard to come by, but there will be many strings attached.

Various other forms of support from China are mentioned in the programs. For contrast, Britain is held as an example for withholding its aid of $\$ 500$ million (See $\underline{\text { Africa's food }}$ security. In the same program, a scholar from Beijing summarizes the aid that China can offer to Africa:

Firstly, the overhaul of the infrastructure across the nation is the area where China has the specialty, has the managing capacity, the capital, and the technological knowhow. Secondly China has been strong in the areas of project engineering. And China has the experience of running and building up the Small and Medium sized Enterprises which are badly needed in Libya to provide more jobs for the people. And fourthly, China as a friend of Libya can help Libya to regain access to the international community.

\section{China's construction of the African image}

One of the goals of Africa Live is to present an image of Africa that is different from that projected by the West (e.g., The changing face of Africa; Charting a new economic path; Africa's food security). Discussions on the changing image of Africa are found in different programs, the West again being held as the 'other' for damaging Africa's image. The program below is an example of the presenter putting a big question mark on the advocacy of the Lord's Resistance Army and the use of soldiers for war, which Africa Live believes will lead to reinforcing the negative image of Africa:

Lord's Resistance Army

P: Do you believe any meaningful change will come out of the advocacy, or is it just stereotyping Africa, that kind of prejudice has been put on the continent for a long time? 


\section{Questioning USA's behavior in Africa}

It is a widely held perception that China is in Africa for its rich natural resources. With its own platform in Nairobi, China can not only deflect Western criticism, but also challenge the USA's intentions in Africa as a form of pushback. Similar to Africa News, two programs (Lord's Resistance Army and Africa's Oil Wealth) in Talk Africa question the coincidence of raising the awareness of the LRA and the use of children for war when it is no longer a threat, and sending 100 American soldiers to that region nevertheless. As the participants do not see it in the same way (calling the same group as 'US support') the presenter tries to remind them they are soldiers rather than support to help them.

As the discussant goes off into other directions without answering the question why American soldiers are in Uganda after it announced that it may have found oil, the presenter insists an answer from him:

P: I just want to revisit the question of strategic interests of the w orld's energy consumers, and recently the international community became proactive again in Somalia at the time Somalia was announcing that it may have found oil. America $\underline{\text { has also sent about } 100 \text { troops to Northern Uganda at a time that Uganda }}$ announced it may have found oil. Does oil drive policy now?

Some scholars have noted that China can be seen to have been socialized into accepting the dominant norms of international behaviour in the US-led post-Cold war international system, which implies the relationship between the USA and China should continue to improve, with their identities and values gradually converging closer together. Lee (2010: 264) also argued that since 2002, China has decided not to contest U.S. global supremacy. However, the examination of the program shows this is no longer the case. China has seemed more willing to engage in wars of words with the United States over areas of disagreement in the international arena than at any time since it introduced its reform and opening policies more than three decades ago. As China continues to assert a greater presence in international affairs and attain greater power and capabilities, it will continue to come into direct contact with the USA across a whole host of spheres.

\section{Challenges -- when the presenter encounters liberal-minded participants}


Throughout the program there is one noticeable feature: unlike the talk show at home, where discussants are supposed to bring in different perspectives, very often it is between the presenter and the discussants who disagree on Talk Africa. For instance, while the Presenter has repeatedly tried to establish a link between election and political instability which is unfavorable for economic development, answers from many liberalminded participants are always that revolution is a good thing. Some of them attribute the instability not to the election itself but to the abuse of the election system. Hence a lot of discussions by interviewees or participants are about setting up credible institutions and systems above leaders, legitimacy, civil society, credible operations of power within the nation, setting up the infrastructure for the elections and improving governance, all of which are taboo topics in Chinese domestic media.

Examples of discussants disagreeing with the presenter can be found in Senegal's election when Dr Zounmenou, head of the African Conflict Prevention and Risk Analysis Program of the Institute of Strategic Studies in South Africa, criticized the political manipulation of electoral processes. On foreign interventions in Africa $\mathrm{Mr}$ Wetangula, Kenya's Foreign Minister in New Hope for Somalia argues for more international attention to Somalia, and Awad Ashareh, a member of parliament for Somalia, welcomes the re-engagement of the international community; $\mathrm{Mr}$ Wafula Wamunyinyi, Deputy Chief of the Mission of the African Union Force in Somalia, known as AMISON, also the Representative of the Chairperson of the AU Commission, shows gratitude to the UN Security Council for increasing the number of AU forces in Somalia, and James Gondy, Head of the Kenya Office International Centre for the Transitional Justice, disagrees with the Presenter that the ICC has a biased approach; Muhammed Ihseen, a leading consultant in the oil and gas industry, disagrees with the presenter on the intentions and interests of world oil consumers. There are many more examples where the discussants give completely unwanted answers to the presenter.

One wonders if this kind of discussions may bring unintended consequences on domestic audiences. After all, although CCTV News is targeting at the international audience, research has shown that the English program CCTV is watched by many Chinese English learners. However, the impact, if any, is limited because the time the program is shown is in the small hours of the day in China, making it unlikely that many people would be watching the debates. 


\section{Faces of Africa}

An examination is also conducted of the 15 half-hour archived weekly documentaries aired on Monday from the first one of the series on 23 of January, 2012, to 30 of April 2012.

Table 2

\begin{tabular}{|l|l|}
\hline Date & Title \\
\hline 23.01 .2012 & The last Oloibon \\
\hline 30.01 .2012 & Polygamous love \\
\hline 06.02 .2012 & Con serving the future \\
\hline 13.02 .2012 & Matatu: My life, my art \\
\hline 20.02 .2012 & Sahar's goal \\
\hline 27.02 .2012 & Kipchoge Keino: The runner \\
\hline 05.03 .2012 & Tiken Jah Fakoly: Songs for society \\
\hline 12.03 .2012 & All about love \\
\hline 19.03 .2012 & Aslam flying high \\
\hline 20.03 .2012 & Our film future \\
\hline 02.04 .2012 & Masindi dreams \\
\hline 09.04 .2012 & A millionaire's dream \\
\hline 16.04 .2012 & Kaveke: Fashion redefined \\
\hline 23.04 .2012 & Grace under pressure \\
\hline 30.04 .2012 & Football fever \\
\hline
\end{tabular}

As the table above shows, the documentaries are about African people's lives, dreams, customs and culture, education, music, sports, fashion, and inspiring stories of people who made their success through hard work in spite of hardship. They are stories of support, sharing and love.

This program not only effectively balances out the unusually negative reports on Africa in the news program Africa News but also gives a social and cultural perspective to the African narrative. 


\section{Conclusion}

China's presence in Africa dwarfs many other powers (Shambaugh 2011: 22). Although it has developed at a slower pace in comparison to other sectors, China's state media has recently gained great momentum in Africa. It is making great efforts to increase its influence in Africa and in the world as an instrument of China's grander soft power engagement and for the construction of a discourse that is not only an alternative to the West but also to challenge the existing US-led world order.

However, although China is increasingly seeking to project the image of a great power able to assume the responsibilities, China's rapid rise means it has to deal with a whole set of questions and external demands that it has never experienced before. What CCTV Africa is doing is a reflection of what is happening with in China itself - learning by doing. It is apparent that Africa Live is a platform for China to prepare itself for its new international status. To that end, Africa News does not follow CCTV's usual practice of prioritizing positive reporting in its news program so that it is more attractive to the international audience. For the same reason, topics of discussion such as elections and democracy that are not able to make their way to the talk show at home appear in the programs constantly. To ensure the expression of more subtle views on African and African related international issues, CCTV Africa has also actively sourced local and international personnel to work under Chinese managers. Currently it has over seventy local employees while only over forty are from China. Interviews with both local and Chinese employees show that the local employers, the majority of whom have worked in private media companies, bring with them different experiences to their new jobs. It also changes its conventional way of crude propaganda by either citing African media sources or giving African participants the platform of Africa Live to tell their stories.

Harmony, the core value that China is trying to promote, is understood to be the peaceful co-existence of different cultures, values and systems. That is to say, the main goal of a harmonious world advocated by $\mathrm{Hu}$ Jintao is not to share culture or values globally, but to allow different systems to co-exist peacefully. In promoting the coexistence of different systems, be it the one-party system in China or any other in Africa, CCTV lashes at the conditions-attached approach by the West in Africa. Local participants on the program are given the chance to say that the democracy practiced in their own countries is far superior to the one in the West. 
The examination of the one hour program Africa Live shows a China that no longer chooses to work with the current world order that is believed to be biased in favor of the West (Chan 2008). It wants a fundamental change in the global order. In so doing, China lines up with African countries by expressing camaraderie with 'the victimized'. In addition, it promotes a positive image of China, highlights Western intervention and interference in African affairs, condemns the international system (e.g., ICC) for targeting Africa, which brings damage to the image of Africa, and thus investment in Africa; it accuses the international system (e.g., the NATO Allies) of not respecting the AU in dealing with African affairs; it challenges the World Bank for automatically giving the Presidency to an American rather than an African, thus raising a question mark on the merit and transparency of the selection process; it also questions the intentions of the US for sending troops to Uganda when there is no danger any more but speculation of oil in that region. The programs thus also have a goal of 'educating' the public in Africa that the West is to blame for many of its failures.

Challenges for the international systems and the USA in China's state media discourse indicate that a more assertive China is emerging. However, the state media discourse contains only condemnation of the West and the West-led international system. What is obviously absent is the alternative discourse that China can offer to the world, except that the current international system should allow the co-existence of different systems.

To conclude, China is trying to build up its challenging power, but no substantial content can be found from the discourse of a state media as an alternative to the West. China is aware of its lack of experience in playing the global power and the lack of a discourse that is strong enough to counter the hegemony of the US-led Western discourse. Among other goals, Africa Live therefore also serves as a platform to experiment with and strengthen China's 'power of discourse'. However, what it is doing now is only 'educating' the African media public that the West is not true friends like China, but has been victimizing Africa. This absence of a clear discourse on a new world order indicates that China may be verbally assertive and sometimes becomes harsh in its condemnation and criticism of the West and the USA, however, it is not more than a way of pushbacks. It should also be read in the context of internal economic and social limitations. Although Chinese state media targeting at international audiences 
has less constraint its discourse is a work-in-progress that reflects internal practises such as the paramount importance attached to stability and anything that has consequences on stability, whether revolution or election, is considered undesirable. As a number of topics discussed in the program are taboo topics in the domestic media, professionals do not have enough expertise to handle with this kind of topics, which is demonstrated in Talk Africa, when discussants disagree with the presenter strongly. It means although there seems to be domestic agreement at present to play a more confident role, China, a global power and a developing country at the same time, is still trying to find its way as a great power in the international system which is itself changing fast.

\section{Acknowledgement}

I am very grateful to the University of Nottingham and Chiang Ching-Kuo Foundation for their generous financial support which enables me to carry out interviews in Beijing and Nairobi. I also wish to thank all the informants who have spent time to talk to me.

\section{References}

Brautigam, D. 2009. The dragon's gift: the real story of China in Africa Oxford: Oxford University Press.

Callahan, W.A. 2012. Harmony, unity and diversity in China's world. The Newsletter, 60 Summer, pp. 22-23;

Chan, G. 2008. China joins global governance: the 10 conundrums. In China and the new international order, ed s. G. Wang and Y. Zheng, 168-184. USA: Routledge.

He, W. 2007. The Balancing Act of China's Africa Policy. China Security, Vol. 3 No. 3 Summer: $23-40$.

Hu, A., Yan, Y. and Wei, X. 2012. China 2030. Beijing: Renmin University Press.

Hu, J. 2012. Open up New Prospects for A New Type of China-

Africa Strategic Partnership. http:/ / www .chinadaily.com.cn/ china/ 2012-

07/ 19/ content_15600866.htm (accessed 1st of December, 2012).

Lam, W. 2009. Chinese State Media Goes Global: A Great Leap Outward for Chinese Soft Power? China Brief. Vol. 9 Issue 2, 
http :/ / www .jamestown.org/ single/ ?no_cache=1\&tx_ttnews\%5Btt_new s\%5D=34387 (accessed $4^{\text {th }}$ of May, 2012).

Large, D. 2008. China and the contradiction of non-interference in Sudan Review of African Political Economy, 35 (115): 93-106.

Lee, C. 2010. Bound to Rise: Chinese Media Discourses on the New Global Order. In Reorienting Global Communication: Indian and Chinese Media Beyond Borders, ed s. M. Curtin and H. Shah, 260 - 304. USA: University of Illinois Press.

Massey, Nathanael. The Satellite War for Hearts and Minds, http:/ / w w w.bestthinking.com/ trendingtopic/ relateditem/ 3842 (accessed 24 Sept., 2012).

Rotberg, R.I. 2008. China into Africa: Trade, Aid, and Influence. Brookings Institute Press.

Shambaugh, D. 2011. Coping with a Conflicted China. The Washington Quarterly, Winter: $7-27$.

Shen, D. 2012 China's leadership transition and foreign policy, East A sia Forum:

Economics, Politics and Public Policy in East A sia and the Pacific,

http :/ / w ww .eastasiaforum .org/ 2012/ 10/ 08/ chinas-leadership-transition-and-foreignpolicy/ (accessed $3^{\text {rd }}$ of October, 2012).

Sheng, D. 2008. To Build a 'Harmonious World:' China's Soft Power Wield ing in the Global South Journal of Chinese Political Science. 13(2): 193-213.

Steinfeld, E. 2010. Playing Our Game: Why China's Rise Doesn't Threaten the West. USA: OUP.

Strauss, J. and Martha S. 2009. China and Africa: Emerging Patterns in Globalization and Development. The China Quarterly 199, September.

Wang, T. General Secretary Hu Jintao's 'Four More Powerful' Gives Clear Direction for Future Directions for Foreign Policy. http:/ / opinion.people.com.cn/ BIG5/ 1036/ 9690180.html (accessed 22 ${ }^{\text {nd }}$ August, 2012).

Wen J. 2008. Report on the Work of the Government 2008, http:/ / english.gov.cn/ official/ 2008-03/ 20/ content_924600.htm (accessed 20 Sept., 2012).

Yan, H. \& Barry, S. 2012. Chasing Ghosts: Rumors and Representations of the Export of Chinese Convict Labor to Developing Countries. The China Quarterly. Volume 210: 398 418.

Zhang, J. 2008.China's Foreign Policy Enters the Era of Discourse of Pow er. Southern Wind Window, Issue 6. 
Zhao, Q. 2011. The Importance of Public Diplomacy. Paper presented at the conference on 'the New Land scape of Global Communication,' Renmin University, July 4-5, 2011, Beijing.

2011. The Chinese in Africa: Trying to pull together, The Economist, 20 April, 2011. http:/ / www .economist.com/ node/ 18586448 (accessed $3^{\text {rd }}$ of August, 2012.)

http:/ / cctv.cntv.cn/ lm/ talkafrica/ 01/ index.shtml (accessed $1^{\text {st }}$ of December 2012.)

http:/ / english.gov.cn/ 2012-11/ 08/ content_2260273.htm (accessed 12 $2^{\text {th }}$ December, 2012.)

China-Africa relations. http://www.cpcchina.org/2012-02/02/content_14526996.htm (accessed March 1st, 2013) 